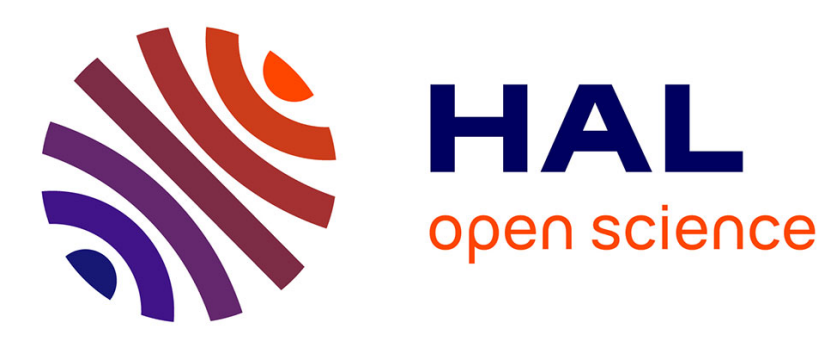

\title{
SME dependence and coordination in innovation networks
}

\author{
Elodie Gardet, Caroline Danièle Mothe
}

\section{To cite this version:}

Elodie Gardet, Caroline Danièle Mothe. SME dependence and coordination in innovation networks. Journal of Small Business and Enterprise Development, 2012, 19 (2), pp.263-280. 10.1108/14626001211223892 . hal-00919206

\section{HAL Id: hal-00919206 \\ https://hal.science/hal-00919206}

Submitted on 16 Dec 2013

HAL is a multi-disciplinary open access archive for the deposit and dissemination of scientific research documents, whether they are published or not. The documents may come from teaching and research institutions in France or abroad, or from public or private research centers.
L'archive ouverte pluridisciplinaire HAL, est destinée au dépôt et à la diffusion de documents scientifiques de niveau recherche, publiés ou non, émanant des établissements d'enseignement et de recherche français ou étrangers, des laboratoires publics ou privés. 


\title{
SME dependence and coordination in innovation networks
}

\author{
RESEARCH PAPER
}

\section{Elodie Gardet}

elodie.gardet@univ-savoie.fr

\section{Caroline Mothe}

caroline.mothe@univ-savoie.fr

IREGE, University of Savoie, 4 chemin de Bellevue, BP 80439, 74944 Annecy le Vieux, France

\begin{abstract}
Purpose: The objective of this research is to identify and characterize the coordination systems used by SME hub firms that are in a situation of dependence with respect to other members of their network, taking into account the influence of hub firm size.

Design/methodology/approach: Seven case studies were carried out: six innovation networks in which SMEs play a central role are compared with a "reference" case, in which the hub firm is a large company.

Findings: Our qualitative empirical analysis of seven innovation projects showed that (1) the sharing of benefits and the guarantees that are implemented vary depending on the hub firm's degree of dependence, (2) trust and recourse to formal agreements differ according to hub firm size, and (3) conflict solving is influenced by both hub firm size and degree of dependence.
\end{abstract}

Practical implications: Results have important implications for the management of innovation networks which are increasingly important for the development of SMEs. The knowledge of the adequate coordination mechanims is central for a SME hub firm and the success of the innovation project.

Originality/value: Investigations into the internal operation of inter-organizational networks have become increasingly common. Nevertheless, empirical studies are still rare, particularly in the field of innovation networks and even more in the case of networks set up by small firms. This article partially fills this gap.

Keywords: coordination, dependence, small and medium-sized firms, hub firm, innovation network, size 


\section{INTRODUCTION}

Many researches have stressed the strong involvement of Small and Medium-sized Enterprises (SMEs) in innovation activities. These are often carried out as part of collaboration projects, especially within innovation networks (e.g. Batterink et al., 2010). However, empirical studies on the internal management and orchestration of innovation networks are scarce (Dhanaraj and Parkhe, 2006), in particular as far as SMEs are concerned. Batterink et al. (2010) are the exception but they focus on external innovation brokers and not on hub firms. Most research has focused on the creation, the structure or the factors leading to the collapse of the firms.

Such absence of research is all the more surprising that these organizational forms facilitate information exchange and the transmission of knowledge, which encourages opportunistic behaviour (Goerzen, 2007). This type of behaviour can be exacerbated when the hub firm is an SME, especially when these networks include (very) large size organizations. In their review of the existing empirical data on SME networking, White et al. (1996) have considered the relative costs and benefits of membership. The authors discussed the possible role played by network brokers in reducing these risks and supporting the development of mutually beneficial, growth-oriented relationships between high-technology SMEs. Very recently, Ngugi et al. (2010) advocated that further studies be undertaken in order to explore the relational capabilities of SMEs in wider relationships, such as within networks. In line with these studies, we focus here on innovation networks that are co-ordinated by small firms. Our analysis addresses networks including high-tech SMEs, but also those led by an SME regardless of the nature and size of the network members. It also focuses on the capabilities that lead to the implementation of ways to improve coordination between the hub firm and its network members. More precisely, our goal was to identify how an SME can coordinate 
network members and also to analyze the coordination arrangements that are implemented, especially when the small hub firm is in a dependency situation towards one (or more) member(s).

Indeed, this link between a hub firm's level of dependence, particularly when the hub firm is small, and the coordination mechanisms adopted by this hub firm has not yet been studied. Besides, research on coordination mechanisms has addressed the mechanisms individually (Das and Teng, 1998). Our study aimed to remedy this situation by analyzing the various coordination mechanisms set up within innovation networks where the hub firm is an SME. Indeed, asymmetry in size between the different network members tends to affect how alliance relationships are managed (Oliver, 1990) - even though size is not always associated with dependency. Our research thus departs from previous work through:

- The analysis of several coordination mechanisms: empirical research has, until now, focused on one or two coordination mode(s). Theoretical research, for its part, provides conceptual frameworks including a variety of conceptual frameworks with various coordination mechanisms. These are quite complex however, making their operationalization rather difficult.

- A detailed analysis of coordination mechanisms: we take a further step toward understanding the "mechanisms" by studying the various dimensions that they may adopt;

- The identification of the impact of small size for hub firms and, more generally speaking, of the type of dependence on coordination mechanisms. Indeed, size asymmetry between members affects the management of alliance relationships. We thus answer the following question: Does the coordination mechanism differ depending on whether the hub firm is small or large?

The objective of this article is to show that dependency and size are key elements in understanding the coordination mechanisms established by hub firms within innovation 
networks. The emphasis is placed on hub firms because these hold a central position in the innovation network structure and take on a leadership role by channelling the network members' scattered resources and capabilities (Dhanaraj and Parkhe, 2006). They also possess some fundamental resources (patent and property rights) and have authority over the other members. The hub firm is also the organization that has established the largest number of links with the other network members.

The article is structured as follows. Section 1 reviews the relevant literature on innovation in SMEs, elaborating on the inter-organizational context of innovation. More specifically, we discuss the importance of SME-driven innovation networks, addressing how these networks are managed, the various coordination mechanisms a hub firm may adopt, and the difficulties linked to the SME hub firm's dependency. In Section 2, the methodology of the empirical research is described. This section introduces the seven innovation networks that were investigated, and describes in detail how the data was collected and analysed. The seven innovation networks are then examined in order to compare the coordination mechanisms adopted by six networks orchestrated by an SME with a seventh network driven by a large firm. Section 3 discusses the findings from the cases and derives research propositions. The conclusion presents the limitations of the study and proposes avenues for further research.

\section{COORDINATION AND HUB FIRM DEPENDENCY IN INNOVATION}

\section{NETWORKS}

Innovation in SMEs has been the subject of numerous studies, part of which addressed the question of why large firms and SMEs do not deal with cooperation and innovation in the same way. Indeed, SMEs have specific characteristics and often lack essential resources and capabilities to successfully innovate exclusively by means of in-house activities (Narula, 
2004). This makes inter-organizational networks essential for SMEs innovation processes. In recent years, various national policies have endeavoured to boost firms' innovation activities by stimulating inter-organizational cooperation among SMEs, often through cluster policies. Focusing on innovation networks established by SMEs, we present the main stakes of innovation networks for such enterprises (1.1), the various mechanisms a small hub firm may call upon in order to coordinate all network members (1.2). Also, as the hub firm is often dependent on some of the network members, we detail the sources of that possible dependence relationship (1.3).

\subsection{INNOVATION NETWORKS AND SMES}

Research has evidenced that some SMEs benefit from cooperation for their innovation processes, whereas others experience major problems. The positive effects include increased turnover, higher profit rates and expansion of the product range (De Jong and Vermeulen, 2006). However, SMEs often find it difficult to establish and benefit from inter-organizational innovation projects. One of the reasons is that smaller companies cannot enforce their will upon others (Batterink et al., 2010). The distribution of the results is therefore a key issue for them. In addition, typically for SMEs, knowledge may unintentionally spill over to other organizations. Finally, inter-organizational innovation projects may involve organizations with diverging corporate and cultural backgrounds, thus leading to coordination problems. These usually increase proportionally to the number and diversity of the organizations involved. It is thus essential for a hub firm, especially an SME, to be well informed of the potential pitfalls of cooperation within networks, so as to mitigate these via appropriate coordination mechanisms. In their study of 164 Austrian SMEs, Hoffmann and Schlosser (2001) showed that coordination (such as a precise definition of rights and duties) is a key

success factor of cooperative arrangements. However, SMEs often lack the capacity to fulfil 
such key success factors for successful coordination and network management (Hoffmann and Schlosser, 2001). How then are such networks managed? This article aims to answer the following main research question: how does an SME hub firm coordinate innovation networks?

Surprisingly, little attention has been paid to these network orchestration processes aimed at innovation, and research has yet to analyze the contributions a hub firm can make to the network it orchestrates, despite its lack of hierarchical authority (Dhanaraj and Parkhe, 2006). In line with Dhanaraj and Parkhe (2006), an innovation network is defined as a set of vertical and horizontal relationships established between various organizations (public/private, partner/service provider) that are orchestrated by the hub firm in order to take advantage of its invention(s). The hub firm is the organization that has filed the patent(s) and needs to call upon a number of other companies in order to take full advantage of these. Its objective is to regulate the transactions within the innovation network (Powell, Koput and Smith-Doerr, 1996) through the use of coordination mechanisms.

\subsection{COORDINATING INNOVATION NETWORKS FOR A HUB FIRM}

Coordination mechanisms are viewed as arrangements between economic entities, governing how these latter cooperate in order to develop an innovation project (Grandori and Soda, 1995). The advantage of this definition is that it focuses on interactions on a strategic level, rather than on an operational level (such as the division of tasks or means of communication). Coordination within inter-organizational relationships can be achieved through five main mechanisms (Das and Teng, 1998; Grandori and Soda, 1995): the type of exchange, trust, sharing of benefits, guarantees and conflict resolution.

Type of exchange. Members within an innovation network must lay out rules for acceptable behaviour, either formally or informally, in order to govern aspects such as how the results 
will be divided, conflicts resolved, etc. (Poppo and Zenger, 2002). Formal, explicit and written modes include standardized procedures, technical reports, analytical accounting, budgeting and planning methods, confidentiality agreements and contracts (Das and Teng, 1998). Informal, implicit and verbal exchanges include the creation of joint teams (Grandori and Soda, 1995), seminars, meetings and staff transfers and decision-making methods. Informal modes are less costly, increase strategic flexibility and reduce the risk of conflict (Nooteboom et al., 1997). However, they require more time to implement (Das and Teng, 1998). In an innovation network, any delay in launching the product on the market may lead to that product being obsolete.

Inter-organizational trust. It is defined as an underlying psychological condition that may be the cause, or the result of a specific behaviour (cooperation) or a choice (risk) (Woolthuis et al., 2005). Trust is often considered to have a direct influence on the success of partnerships, especially within the uncertain environment of an innovation project where trust can serve to predict the network members' behaviour (Ring and Van de Ven, 1994). In these networks, unforeseen events occur on a daily basis, making it hard for contracts to be fully comprehensive.

Result division. An equitable division of results is often perceived as an incentive, encouraging project members to work harder, thereby improving the performance of an innovation project. On the other hand, an equal sharing of benefits can be seen in terms of uniformity and a lack of differentiation between the members of the project. Every member receives an equal share of the results, no matter how much they contribute in terms of resources and/or expertise (equal share in the results, regardless of the investment). This type of sharing is risky when the members bring unequal contributions as it can lead to the impression that the sharing of benefits is unfair. 
Guarantee systems. Set up as prevention systems against opportunistic behaviour, they provide protection against potential damage by ensuring that it will be expensive for opportunistic members to withdraw from the network. Different guarantees have been described and financial integration is not the only way of ensuring members' loyalty. Other methods include logistic integration (control of capital flowing from a member), media-based integration (promotion of a brand that will be instantly recognized by all the network's customers) and cultural integration (use of organizations that have a relationship with the hub firm that is not exclusively economic). Rubin (1990) suggested using reputation and/or specific assets. Future business opportunities also represent a guarantee, as the opportunistic member will experience a decrease in its future business in the case of withdrawal. Innovation networks do not always resort to guarantees. And guarantee mechanisms (direct and indirect) are not mutually exclusive : several guarantee mechanisms, especially when there is a high risk of opportunism, can be used.

Conflict resolution. Within an innovation network, it is necessary to consider all interactions: two-to-two, one-to-several and several-to-several. Hence, if a conflict arises between two technical partners, another member of the network (most likely the hub firm) may intercede to resolve the issue. This type of situation has not been addressed in the literature. Conflict resolution mechanisms in innovation networks are complex, as is it hard to foresee how an innovation project will develop. Besides, the level of network members' commitment is heterogeneous. Mohr and Spekman (1994) described six such mechanisms in bilateral relations. For the study of innovation networks, we have retained five (domination being considered as equivalent to coercion) : (1) Joint resolution of a problem: the different parties agree to work together in order to find a mutual solution to a problem, (2) Persuasion: one of the parties tries to persuade the other members that solution A or B represents the best way to emerge from a conflict situation, (3) Coercion: one partner forces the others to choose its 
preferred solution for resolving the conflict, (4) Sanction: the network member is expelled, and (5) Introduction of a third party: recourse to arbitration (arbitrator or legal action).

These five coordination mechanisms can be used by SME hub firms in order to orchestrate their innovation networks. Note that the specificity with innovation networks (compared to bilateral alliances for instance) is that these mechanisms have to be implemented with each member. However, the relationship between the hub firm and each member is different, not only because the members may operate in different fields (technical, financial, commercial, etc.), but also because the hub firm might be in a situation of dependence vis à vis some members, and not vis à vis others. Consequently, the question remains as to whether these coordination mechanisms vary according to the dependent or non-dependent relationship the hub firm has with the network member firms.

\subsection{SME HUB FIRM DEPENDENCY WITHIN INNOVATION NETWORKS}

Through networks, organizations seek to increase their respective power by gaining control over resource flows. Dependency arises from the hub firm's need to maintain its relationship with one or more member(s) in order to achieve its innovation objectives.

The resource dependency approach (Pfeffer and Salancik, 1978) proposes a unified theory of power at the organizational level of analysis which makes it possible to analyze the dependency relations that an SME hub firm has with some of the innovation network members. Organizations hold power over other entities when they control resources needed by these latter, they are also in a position to reduce their dependency on others with respect to resources (Provan et al., 1980). Power can be defined as the ability to impose one's will onto others; the power of A over B is the ability of A to make B do something that A would not have done without the intervention of A (Dahl, 1957). The essence of power arises from one party's dependence upon another (Blau, 1964). 
Dependency has been the subject of multiple studies, especially concerning dependence towards customers (Raymond and St-Pierre, 2004), but not within innovation networks. In the latter case, a hub firm may be dependent upon several (types of) partners within the network. We investigated hub firms' negotiating power and dependency according to five elements:

Partner size. A larger partner generally has greater negotiating power in the interorganizational relationship (Oliver, 1990). In an innovation network including a small firm and a large firm, the first will often be in a position of dependency. Needing the additional resources provided by its partners creates a balance of power that is unfavourable.

Partner resources. Each partner's negotiating power is determined by the resources it provides, which can be either tangible (e.g., finance, skills, expertise) or intangible (e.g., reputation, network of relations). The type of resources provided determines a partner's level of dependence, hence its power (Blau, 1964). Resources are key in complementary innovation networks in which the hub firm looks at having access to its partner(s) resources.

Strategic importance of the project. The larger the proportion of the business taken by the innovation network, the greater the partner's dependency on the other members (Pfeffer and Salancik, 1978) and the weaker its power. Hence, dependency is linked to the strategic importance of the project for the firm, which is supposedly greater for a small hub firm.

Uncertainty. Power relationships are also linked to uncertainty, which can weigh upon the partners in terms of the unpredictability of their behaviour or the absence of complete convergence of their objectives (Sutcliffe and Zaheer, 1998). The existence of alternatives can make a partner's behaviour unpredictable and reduce its dependency.

The urgency of cooperation. The time factor also affects partners' respective powers within an innovation network (Weigelt, 2009). The absence of pressing time constraints is a considerable advantage in a power relationship. Members in an innovation network needing 
to achieve results within a limited time frame will be at a disadvantage with respect to the other members.

Having identified the main coordination mechanisms and sources of hub firm dependence, our objective is to explore how the mechanisms are used, and whether this use varies according to the type of dependency.

\section{EMPIRICAL CASE STUDY OF SEVEN INNOVATION NETWORKS}

In order to answer our main research question ("how does an SME hub firm coordinate innovation networks?") and to explore the potential relationships between coordination mechanisms and hub firm dependency, a qualitative case study methodology seemed the most appropriate methodology (Yin, 1994). Indeed, the objective was to gain a comprehensive and in-depth understanding of how coordination mechanisms were used and how they might vary as a function of hub firm dependency within innovation networks.

\subsection{METHODOLOGY AND FIELD}

The seven case studies constitute the theoretical sample (Glaser and Strauss, 1967). We selected cases that had the following common characteristics: the network was steered by a hub firm and was composed of at least three companies; the project was based on applied research and sought to develop a technological invention protected by a patent, design or model - as this research was limited to technological product innovations. We neutralized these four factors by choosing cases with these characteristics. In addition to the theoretical population, variety was a second criterion to be met in order to understand the phenomenon and its complexity. Several contextual variables were included with the objective of increasing result generalization: 
- Number of members, used in most research on interorganizational networks (Ahuja, 2000 ; Goerzen, 2007): the studied networks had between 4 (Pinc\&pile) and 55 members (Motorisation);

- Geographic spread of the network, in order to assess the geographical proximity between members (local, national or international);

- Size of hub firm and number of employees in the project (Reuer and Arino, 2007), in order to evaluate the importance of the project for the hub firm;

- Previous experience of cooperation projects, as a company with a history of cooperative relations will have experience in managing such relationships (Nerkar and Roberts, 2004);

- Resources and skills possessed by the hub, as it is important to consider the type of resources and skills possessed by network members (Goerzen, 2007);

- Hub firm resources and skills (Goerzen, 2007);

- Sector of activity, in order to evaluate whether results vary according to the field of activity: the case studies concerned innovation projects in different sectors (sports and leisure, plastics and rubber, paper and packaging, automobile, and electrical equipment and electronics);

These characteristics are factors that may influence the coordination mechanisms in an innovation network. However, no influence of these variables was detected in our case analysis (apart from the fact that hub firms look for complementary resources and competences when selecting of their partners).

Fifty seven semi-directive interviews (Table 1) of one hour and a half on average were carried out with the project bearer and the financial, technical, industrial, commercial and legal members. They were designed so to address the coordination modes at work in each of the networks. This research was also conducted using internal (mails exchanged between project members, internal memorandums produced by the project leader, business plans, contracts, etc.) and external secondary data (Internet, hub firms' websites, press articles). For 
each case, we studied a variety of relationships between the hub firm and the various

technical, financial, industrial, commercial and legal partners (about hundred relations ${ }^{1}$ ).

Table 1

The seven innovation networks studied

\begin{tabular}{|c|c|c|c|c|c|c|}
\hline Project & Hub firm & $\mathbf{M}^{*}$ & Subject & Business sector & Characteristics & $\mathbf{I} * *$ \\
\hline Project A & $\begin{array}{c}\text { SME } \\
\text { (12 people) }\end{array}$ & 65 & $\begin{array}{l}\text { Essential component } \\
\text { for automobile } \\
\text { manufacturers }\end{array}$ & Automobile & $\begin{array}{l}\text { Ambitious project: high } \\
\text { investment and very technical }\end{array}$ & 13 \\
\hline Project B & $\begin{array}{c}\text { SME } \\
\text { (2 people) }\end{array}$ & 8 & $\begin{array}{l}\text { Product for } \\
\text { beauticians } \\
\text { (B to B) }\end{array}$ & Large-scale retail & $\begin{array}{l}\text { Conflictual situation: the } \\
\text { commercial and industrial } \\
\text { partner was claiming } \\
\text { property rights on the patents } \\
\text { already filed) }\end{array}$ & 9 \\
\hline Project $\mathrm{C}$ & $\begin{array}{l}\text { Independent } \\
\text { (1 person) }\end{array}$ & 11 & $\begin{array}{l}\text { Product for every- } \\
\text { day use }\end{array}$ & Large-scale retail & $\begin{array}{l}\text { Stagnant project: Oligopolist } \\
\text { target market leading to } \\
\text { distribution problems }\end{array}$ & 6 \\
\hline Project D & $\begin{array}{c}\text { SME } \\
\text { (3 people) }\end{array}$ & 9 & $\begin{array}{l}\text { Machine improving } \\
\text { the efficiency of the } \\
\text { manufacturing } \\
\text { process of small } \\
\text { parts }\end{array}$ & Industry & $\begin{array}{l}\text { Opportunistic behaviour of a } \\
\text { commercial partner: } \\
\text { complementary patent filed } \\
\text { without notifying the project } \\
\text { sponsor }\end{array}$ & 7 \\
\hline Project E & $\begin{array}{c}\text { SME } \\
\text { (6 people) }\end{array}$ & 24 & $\begin{array}{l}\text { Protection products } \\
\text { for sports people }\end{array}$ & Sport and leisure & $\begin{array}{l}\text { Project that is successfully } \\
\text { moving forward without too } \\
\text { many problems }\end{array}$ & 10 \\
\hline Project F & $\begin{array}{l}\text { Independent } \\
\text { ( } 1 \text { person })\end{array}$ & 6 & $\begin{array}{l}\text { New practices in } \\
\text { snow sports }\end{array}$ & Sport and leisure & $\begin{array}{l}\text { The hub firm benefited from } \\
\text { the experience of another } \\
\text { project sponsor }\end{array}$ & 8 \\
\hline Project $\mathrm{G}$ & Large firm & 7 & $\begin{array}{l}\text { High-technology } \\
\text { engineering parts }\end{array}$ & Industry & $\begin{array}{c}\text { Heavy and formal } \\
\text { negotiations }\end{array}$ & 4 \\
\hline \multicolumn{6}{|c|}{ Total number of interviews } & 57 \\
\hline
\end{tabular}

* Number of members; $* *$ number of interviews

For example, in project A, the SME hub firm had relationships with 29 technical members: 11 "partners" and 18 "suppliers". The lack of precision on the number of relationships examined is related to the complexity of our subject: most often, the interviewed persons spoke about a group of members (e.g., technical members) and not about specific firms. 
For each case, a range of relationships was examined (approximately 100 in total $^{2}$ ) between the hub firms and the technical, financial, industrial, commercial and legal members of the network.

\subsection{HUB FIRM DEPENDENCE}

The necessary acquisition of resources and skills was the most frequently encountered source of dependency (five cases: A, B, C, E and F). If a hub firm does not have all the resources and skills required to run a project (production equipment or distribution channels), it often has no other choice than to seek partners; the need for resources and skills then becomes a constraint. The strategic importance of the project has also consequences on the hub firms' dependency. Three of the six hub firms (A, C and F) were created specifically to develop an innovation project and are therefore single product firms. If the project fails, the firm has no further reason to exist and will disappear.

The urgency of the cooperation also affects the hub firms' dependency. Hub firms A, C and D were developing innovations for which several other substitutable technologies could be developed. This meant that they had to get their products on the market very quickly in order to avoid seeing another technical standard take over. For example, for project A, the recent Government incentives aiming to encourage the development of energy-efficient and environmentally friendly vehicles explains the boom in projects focused on developing hybrid engines, but not all of these projects will find a place on the market.

In innovation networks, the number of members is an important parameter (Dhanaraj and Parkhe, 2006). Even when the hub firm is very small, it will not be dependent on all the members (size does not necessarily affect hub firms' dependence). This aspect differentiates our research from previous work on the degree of dependency in inter-organizational

\footnotetext{
${ }^{2}$ The lack of precision in the number of relationships studied is due to the complexity of the subject of our study. The parties frequently referred to a group of members (for example, the technical members), rather than to individual firms.
} 
relationships, which has generally been limited to studies of bilateral alliances. In all the cases, the hub firm depends on some partners, but not on all of them.

\subsection{COORDINATION MECHANISMS DEPENDING ON THE HUB FIRM DEPENDENCY}

We here present only the coordination mechanisms that varied according to the degree of dependence of the hub firm, i.e. division of results, guarantees and conflict resolution.

Sharing the benefits. In innovation networks, two main types of benefits are to be shared:

- Ownership and user rights for the patents and/or plans and models. How they are shared will depend on the size of the hub firm. A small hub firm will seek to keep most of the ownership rights, in order to avoid increasing its dependency on the other members. However, its small size is a weakness that makes it difficult for it to hold on to a majority of the rights;

- Financial income that will be generated by the innovation project. Most hub firms propose to remunerate members via a system of recurrent royalties, payable on a monthly or quarterly basis. These royalties are usually calculated as a percentage of the generated turnover.

When the hub firm is in a position of dependency with respect to the other members, these latter are indispensable to the success of the project. In most of the cases studied here, the benefits were divided equitably, as the members of the networks consider this mode to be the fairest. With this mode, there fewer conflicts arise over the sharing of benefits. If there is no dependency, egalitarian sharing is used, as long as the member has been part of the project from the beginning and has contributed as much as the hub firm.

Guarantees. The greater the hub firm's dependency, the greater its tendency to protect itself using direct guarantees. The withdrawal of indispensable members can jeopardise the future of an innovation project. Hub firms resort to direct guarantees in order to protect themselves 
against opportunistic behaviour and to make it costly for members to withdraw from the project.

Conversely, the less dependent the hub firm, the less frequently direct guarantees are used, as such guarantees generally take longer to set up (investment in specific assets, financial guarantees requiring the signature of contracts). They are also less worthwhile compared with the risk facing the hub firm.

Conflict resolution. In our SME-orchestrated innovation networks, persuasion was the most commonly used conflict resolution method for dependent hub firms, as patents alone do not give a hub firm sufficient protection. In innovation projects, the hub firm is highly dependent on the other members because neither the technical feasibility nor the commercial viability has been proven and the hub firm must convince the other members of the value of its project. This partially explains why the hub firm accepts the conditions imposed by the other members - its small size and its dependency do not allow it to impose its own solution. Even if the hub firm remains an independent entity3, it must be prepared to accept the choices of the other members, or risk seeing the project fail. Conversely, when the hub firm is not dependent on the other members, removing a partner will be the preferred method for resolving disagreements. If members can easily be substituted, the hub firm will prefer to quickly change a partner before there is a significant transfer of resources and skills.

\subsection{THE MAJOR IMPACT OF HUB FIRM'S SMALL SIZE ON COORDINATION MECHANISMS}

The previous section highlighted the influence of hub firms' degree of dependency on certain coordination mechanisms. This dependency not being linked to size, the direct impact of the hub firms' size on coordination mechanisms is analyzed here. Three coordination mechanisms differ according to size: the degree of formalization, trust and conflict resolution.

\footnotetext{
${ }^{3}$ Our definition of an innovation network only includes independent organizations. Consequently, joint ventures were not included in this study.
} 
Degree of formalization. Four of the six SME hub firms had no written agreements (except non disclosure agreement) with members they had already cooperated with, neither with substitutable members. On the other hand, the hub firms preferred to have written contracts with new members because they could not anticipate their potential behaviour. In general, the SME hub firms sought to reduce the degree of formalization, even if only because they did not have the legal resources to draw up the necessary documents.

By contrast, large hub firms draw up detailed cooperation or service provision contracts, seeking to protect themselves as much as possible against potential opportunistic behaviour. In project $\mathrm{G}$, contractual negotiations were long and each version of the contract had to be checked by each member's legal department.

Trust. The degree of trust varied according to whether or not the members had collaborated in the past. This trust is built up progressively through interactions and working together. It also depends on each member's level of commitment. In project $\mathrm{G}$, there is a priori trust between the three companies, even though they have never worked together before. Their reputations and their corporate image are sufficient to create this mutual trust.

Conflict resolution. When the hub firm is an SME that is not dependent on its members, eviction is the most frequently used method for resolving conflicts. Conflicts arising from substitutable members are seen as threats to the long-term future of the project. Numerous confrontations occurred during the first few months of project G. Unlike the other six cases, their members could not easily withdraw from the project because they were under contractual obligations to cooperate. A majority of conflicts arose over the sharing of property rights between the industrial companies and the research laboratories. At first, the members met every month to discuss disputes and to find solutions. After failing to reach an agreement, the companies resorted to coercion to impose their view on the research laboratories. 
Hub firm size influences the degree of formalization, trust and conflict resolution, whereas the degree of dependency affects the sharing of benefits, the guarantees and the mechanisms used to resolve conflicts (Table 2).

Table 2 Key dimensions for coordination mechanisms

\begin{tabular}{c|c}
\hline Coordination mechanisms & Key dimensions \\
\hline Degree of formalization & Size (direct impact) \\
\hline Trust (or mistrust) & Size (direct impact) (if no previous relations) \\
\hline Sharing of benefits & Degree of dependence \\
\hline Guarantees & Degree of dependence \\
\hline Conflict resolution & Degree of dependence and size (direct impact) \\
\hline
\end{tabular}

Table 3 presents the coordination mechanisms according to hub firms' size and dependency.

Table 3 Coordination mechanisms as a function of size and degree of dependence

\begin{tabular}{|c|c|c|c|c|}
\hline \multirow{2}{*}{ 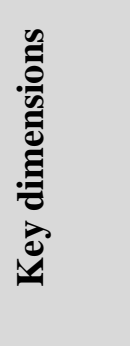 } & \multirow{2}{*}{$\begin{array}{c}\text { Coordination } \\
\text { mechanisms } \\
\text { used by the hub firm }\end{array}$} & $\begin{array}{c}\text { Network } \\
\text { orchestrated by a } \\
\text { large firm }\end{array}$ & \multicolumn{2}{|c|}{ Network orchestrated by a small firm } \\
\hline & & \multicolumn{2}{|c|}{ Non-dependent hub firm } & Dependent hub firm \\
\hline 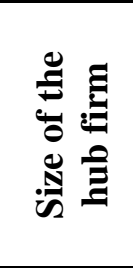 & $\begin{array}{l}\text { Degree of } \\
\text { formalization: } \\
\text { existence (or not) of a } \\
\text { contract and number of } \\
\text { clauses }\end{array}$ & $\begin{array}{l}\text { Very high: every } \\
\text { large firm has its own } \\
\text { legal department. } \\
\text { Contractual } \\
\text { negotiations are long } \\
\text { (1 year) } \\
\end{array}$ & \multicolumn{2}{|c|}{$\begin{array}{l}\text { Moderate: the absence of an internal legal } \\
\text { department means a firm has to use, and pay } \\
\text { for, the services of an external supplier. The } \\
\text { time taken to draw up contracts is short } \\
\text { ( } 1 \text { to } 2 \text { months) }\end{array}$} \\
\hline
\end{tabular}




\begin{tabular}{|c|c|c|c|c|}
\hline & $\begin{array}{l}\text { Degree of trust: (if no } \\
\text { previous relations) }\end{array}$ & $\begin{array}{l}\text { Strong: even if the } \\
\text { members have never } \\
\text { worked together } \\
\text { before, trust is } \\
\text { rapidly built up, as } \\
\text { the members of the } \\
\text { network are large and } \\
\text { have reputations to } \\
\text { protect }\end{array}$ & \multicolumn{2}{|c|}{$\begin{array}{l}\text { Weak to strong: trust is most frequently the } \\
\text { result of previous relations }\end{array}$} \\
\hline \multirow{2}{*}{ 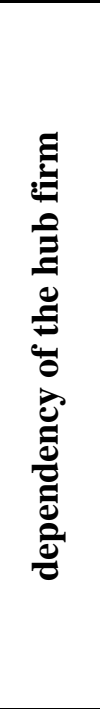 } & $\begin{array}{l}\text { Division of results: } \\
\text { egalitarian or equitable }\end{array}$ & \multicolumn{2}{|c|}{$\begin{array}{c}\text { Egalitarian: as long as the members have } \\
\text { been involved in the project from the } \\
\text { beginning }\end{array}$} & $\begin{array}{l}\text { Equitable: the results } \\
\text { are divided on the } \\
\text { basis of the } \\
\text { contribution made by } \\
\text { each member of the } \\
\text { project }\end{array}$ \\
\hline & $\begin{array}{l}\text { Guarantees: } \varnothing \text {, direct } \\
\text { and/or indirect }\end{array}$ & \multicolumn{2}{|c|}{$\begin{array}{l}\text { Indirect (image and name recognition): } \\
\text { The organizations involved in project } \mathrm{G} \\
\text { have a national, or even an international, } \\
\text { reputation that could be stained by } \\
\text { opportunistic behaviour }\end{array}$} & $\begin{array}{l}\text { Direct and indirect } \\
\text { (future } \\
\text { opportunities): the } \\
\text { hub firm is only } \\
\text { known locally and } \\
\text { cannot rely on its } \\
\text { brand image. SMEs } \\
\text { favour sanctions } \\
\text { against future business } \\
\text { opportunities. }\end{array}$ \\
\hline 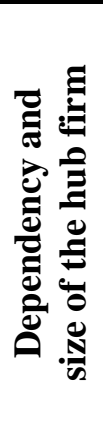 & $\begin{array}{l}\text { Conflict resolution: } \\
\text { joint, persuasion, } \\
\text { coercion, sanction, } \\
\text { recourse to a third party } \\
\text { (arbitration or court } \\
\text { actions) }\end{array}$ & $\begin{array}{l}\text { Discussion then } \\
\text { coercion: recourse is } \\
\text { not made to the } \\
\text { courts or to expelling } \\
\text { members. Expelling } \\
\text { certain members } \\
\text { could have } \\
\text { consequences in } \\
\text { terms of receiving } \\
\text { public finance }\end{array}$ & $\begin{array}{l}\text { Eviction : at the } \\
\text { beginning of the } \\
\text { project, as members } \\
\text { have not yet carried } \\
\text { out significant } \\
\text { transfers of } \\
\text { resources or skills, } \\
\text { the hub firm will } \\
\text { favour expulsion in } \\
\text { the case of conflict }\end{array}$ & $\begin{array}{l}\text { Persuasion by the } \\
\text { dominant member: } \\
\text { thanks to its } \\
\text { negotiating power, the } \\
\text { strongest member can } \\
\text { dictate its choices } \\
\text { because the threat of } \\
\text { its withdrawal could } \\
\text { threaten the future of } \\
\text { the project }\end{array}$ \\
\hline
\end{tabular}

\section{DISCUSSION}

By analyzing the coordination mechanisms that are involved (Dhanaraj and Parkhe, 2006) and by explaining when different dimensions are used with respect to the type of hub firm dependency, this article has highlighted the important role that hub firms may play in orchestrating their innovation networks. The SME hub firm has a central role in establishing and managing the innovation network with the objective of completing an innovation project concerned with transforming a patented invention into a commercial success. 
First, we underline the fact that small size is not always associated with dependency for hub firms. However, due to their small size, SME hub firms are rarely self-sufficient in terms of resources and skills (Park et al., 2002). This is particularly true in the early stages of an innovation project because the hub firm must prove that the project is both technically and commercially viable. However, the hub firm's small size has an impact on the level of formalism involved (which is low, cf. Jaouen and Gundolf, 2009), also on trust (high if there have been previous relations), and on conflict resolution (where a member's exit is more difficult when the hub is large due to often strong contractual commitments). SMEs may choose not to rely on detailed contracts because they are costly to write up, to monitor, and to enforce. Consequently, if they have a history of prior relations with a member SMEs will prefer to rely on trust. These members are likely to have a greater awareness of the rules, routines, and procedures that they are required to follow (Gulati and Singh, 1999). We can therefore propose:

P1: The coordination mechanisms adopted by an SME hub firm differ from those used by a large firm due to a lower degree of formalism, trust if prior relations and easier conflict resolution through member exit.

Second, our research contributes to the resource dependency theory, which becomes a basis for testable empirical research through the identification and measure of resource dependency according to five dimensions. Of these, we have highlighted the major impact of hub firm size, as small size generally implies fewer resources, entailing major resource dependency and power imbalance. The degree of hub firm dependence, which depends on the type of member in these multi-stakeholder networks, has an impact on three coordination mechanisms: distribution of the results, guarantees and conflict resolution. When a hub firm is not in a dependent type of relationship, it will feel more secure and free to disagree on various subjects, including on the most efficient way to allocate joint resources (Kabanoff, 1991). With respect to conflict resolution mechanisms, Mohr and Spekman (1994) have shown their 
importance for the success of a partnership. However, the authors did not study the elements which may affect the choice of coordination modes. In this study, we highlighted the key impact of the dependence level. If a hub firm is dependent, it will not be inclined to take the risk of loosing a partner and will therefore adopt "softer" conflict resolution modes. However, when the level of risk is high (for instance when a member is essential to the project), then contractual guarantees (Das and Teng, 2000) - called "direct guarantees" in this paper - will be implemented. In our case studies, a combination of direct and indirect guarantee was often observed. We thus propose:

P2: The level of dependence of a SME hub firm will have an impact on three coordination mechanisms: result distribution tends to be equitable, guarantees of direct nature, and conflict resolution is usually achieved through persuasion.

The above propositions can be summarized in the following conceptual model (cf. Figure 1):

Figure 1 Conceptual model

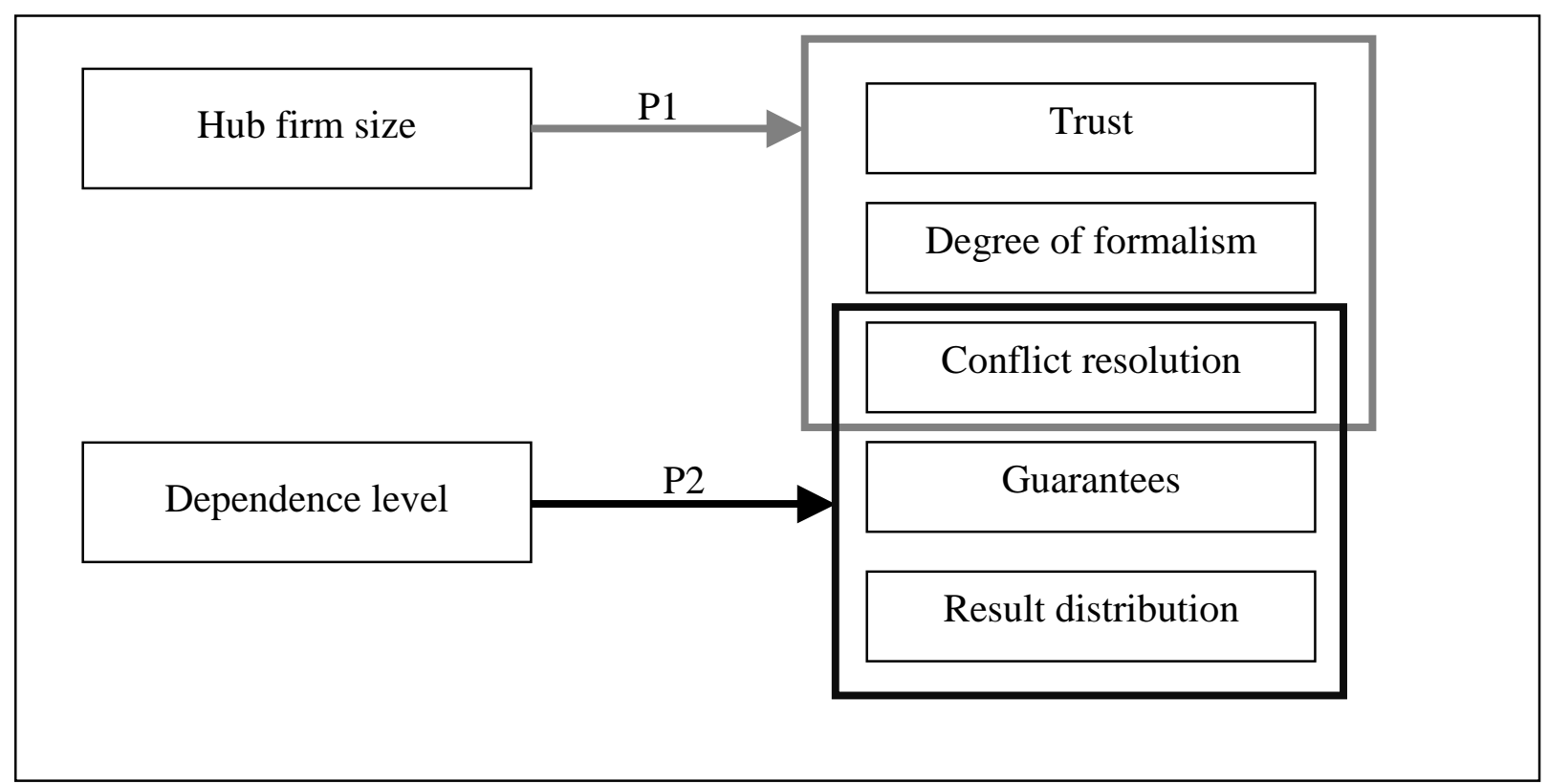

Our results bring major theoretical contributions. We show that, even when the hub firm is an SME (which tends to rely on informal communication modes), a single cooperation approach based on informal or tacit modes of exchange is unrealistic. Only one of our case studies presented a stable network exempt from conflicts of interest or power struggles. Disagreements and divergences of opinion between members are almost inevitable in 
innovation networks. Conflicts of interest and rivalries over power preventing networks from operating smoothly (Miles et al., 1992), some formalization of agreements and coordination modes is a necessary step, even when members have a positive prior experience. This result has implications for theoretical research on trust-based relationships, which has often considered that trust can substitute for contractual engagements. Our results highlight that this is difficult to implement, even when partners know and trust each other due to previous satisfactory relationships (see the case of project D where the hub firm's commercial partner took advantage of the situation by filing an additional patent).

Our results therefore indicate that, for an innovation project-oriented product development, the "relational contract" (MacNeil, 1985) is not suitable. With innovation networks, contradictions and differences of opinion between members are almost unavoidable (Miles et al., 1992), and conflicts of interest and rivalries can often prevent the project from developing harmoniously. In such networks, in line with Poppo and Zenger (2002), a complementarity between contractual relationships and trust seems appropriate.

\section{CONCLUSION}

The present study investigated the influence of a hub firm's dependency and size on the coordination mechanisms established within innovation networks. Analysis of seven innovation projects showed that (1) the sharing of benefits and the guarantees implemented vary according to the degree of dependence of the hub firm, (2) trust and degree of formalization depend on the size of the hub firm and (3) conflict solving is influenced by size and dependence.

These results are important for SME hub firms: indeed, contrary to what is usually proposed for this type of firm (including concerning their dependence on other firms, mainly on large ones), SMEs may find themselves at the head of important innovation networks in 
terms of the number of members and the nature of these members, some of which are multinational leaders in their field. Our research also demonstrates that SMEs are able to manage and orchestrate these innovation networks efficiently by implementing appropriate coordination mechanisms. Most of these mechanisms depend on the hub firm's degree of dependence. For an SME hub firm, the choice of the appropriate coordination mechanism should thus be based on the type and on the degree of the dependence.

Our study carries several limitations, which provide as many avenues for future research. We analyzed the specific context where the hub firm was also the organization that had registered the patent(s). We also used a schematic and simplified view - although the reality is highly complex - considering the degree of dependency and size as dichotomous variables rather than as continuums. Moreover, we analyzed the degree of dependence of the hub firm without studying the degree of dependency of the other members. Coordination mechanisms could also be studied within other types of networks (such as clusters or R\&D consortia), allowing to verify their relevance in heterogeneous contexts. It could also be useful to study whether the mechanisms are affected when there are several hub firms (e.g.: an architect, a lead operator and a caretaker) within an innovation network (Miles et al., 1992). As the present study examined the influence of dependency at a given point in time, future studies could analyze how the degree of dependence evolves as the project advances as a hub firm's dependency is not static and as initial asymmetry can be turned around.

Our results have important managerial implications concerning how SME hub firms, through their managers, select the type of coordination mechanism they will implement. The framework provides guidance for more effective management in innovation networks. Managers should take into consideration the fact that coordination mechanisms are complex and are related to the degree of hub firm dependency and its size. Depending on the degree of dependency, a strategic combination of the five coordination mechanisms can be formulated. 
More generally, this study calls for future work on this important topic in an innovation-based economy.

\section{REFERENCES}

Ahuja, G. (2000), 'Collaboration Networks, Structural Holes and Innovation: A longitudinal Study’, Administrative Science Quarterly, Vol. 45 N³, pp. 425-53

Batterink, M.H., Wubben, E.F.M., Klerkx, L., and Omta, S.W.F. (2010), 'Orchestrating innovation networks: The case of innovation brokers in the agri-food sector', Entrepreneurship \& Regional Development, Vol. $22 \mathrm{~N}^{\circ}$ 1, pp. 47-76.

Blau, P. (1964), Exchange and power in social life, John Wiley and Sons, New York, NY.

Dahl, R.A. (1957), 'The concept of power', Behavioral Sciences, Vol. 2, pp. 201-215.

Das, T.K. and Teng, B.S. (1998), 'Between Trust and Control: Developing Confidence in Partner Cooperation in Alliances', Academy of Management Review, Vol. $23 \mathrm{~N}^{\circ} 3$, pp. 491-512.

Das, T.K. and Teng, B.S. (2000), 'Instabilities of strategic alliances: An internal tensions perspective', Organization Science, Vol. 11, pp. 77-101.

De Jong, J.P.J. and Vermeulen, P.A.M. (2006), 'Determinants of product innovation in small firms - A comparison across industries', International Small Business Journal, Vol. 24 $\mathrm{N}^{\circ} 6$, pp. 587-609.

Dhanaraj, C. and Parkhe, A. (2006), 'Orchestrating Innovation Networks', Academy of Management Review, Vol. $31 \mathrm{~N}^{\circ} 3$, pp. 659-662.

Glaser, B.G and Strauss, A.L. (1967), The Discovery of Grounded Theory: Strategies for Qualitative Research, Aldine Publishing Company, Chicago.

Goerzen, A. (2007), 'Alliance networks and firm performance: The impact of repeated partnerships', Strategic Management Journal, Vol. 28, pp. 487-509.

Grandori, A. and Soda, G. (1995), 'Inter-Firm Networks: Antecedents, Mechanisms and Forms', Organization Studies, Vol. 16 N$^{\circ}$ 2, pp. 183-214.

Gulati, R. and Singh, H. (1999), 'The architecture of cooperation: Managing coordination costs and appropriation concerns in strategic alliances', Administrative Science Quarterly, Vol. 43, pp. 781-814.

Hoffmann, W.H. and Schlosser, R. (2001), 'Success factors of strategic alliances in small and medium-sized enterprises - An empirical survey', Long Range Planning, Vol. 34, pp. 357-381.

Jaouen, A. and Gundolf, K. (2009), 'Strategic alliances between microfirms: specific patterns in the French context', International Journal of Entrepreneurial Behaviour and Research, Vol. $15 \mathrm{~N}^{\circ} 1$, pp. 48-70.

MacNeil, I.R. (1985), 'Relational Contract : What we do and do not know', Wisconsin Law Review, Vol. 3, p. 483-526.

Miles, M.B., and Huberman, A.M. (1994), Qualitative data analysis: An expanded sourcebook. (2nd ed.). Newbury Park, Sage, California.

Miles, R.E., Snow, C.C. and Coleman, H.J. (1992), 'Managing 21st century network organizations', Organizational Dynamics, Vol. $20 \mathrm{~N}^{\circ} 3$, pp. 5-20.

Mohr, J. and Spekman, R. (1994), 'Characteristics of Partnership Success: Partnership Attributes, Communication Behavior, and Conflict Resolution Techniques', Strategic Management Journal, Vol. $15 \mathrm{~N}^{\circ}$ 2, pp. 135-152. 
Nerkar, A. and Roberts, P. (2004), 'Technological and product-market experience and the success of new product introductions in the pharmaceutical industry', Strategic Management Journal, Vol. 25, pp. 779-799.

Ngugi, I.K., Johnsen, R.E. and Erdélyi, P. (2010), 'Relational capabilities for value cocreation and innovation in SMEs', Journal of Small Business and Enterprise Development, Vol. $17 \mathrm{~N}^{\circ} 2$, pp. $260-278$.

Kabanoff, B. (1991), 'Equity, equality, power and conflict', Academy of Management Review, Vol. $16 \mathrm{~N}^{\circ} 2$, pp. 416-441.

Miles, R.E., Snow, C.C. and Coleman, H.J. (1992), 'Managing 21st century network organizations', Organizational Dynamics, Vol. $20 \mathrm{~N}^{\circ}$ 3, pp. 5-20.

Narula, R. (2004), 'R\&D collaboration by SMEs: New opportunities and limitations in the face of globalisation', Technovation, Vol. $24 \mathrm{~N}^{\circ}$ 2, pp. 153-161.

Nooteboom, B., Berger, H. and Noorderhaven, N.G. (1997), 'Effects of trust and governance on relational risk', Academy of Management Journal, Vol. $40 \mathrm{~N}^{\circ}$ 2, pp. 308-338.

Oliver, C. (1990), 'Determinants of Interorganizational Relationships: Integration and Future Directions', Academy of Management Review, Vol. 15 N², pp. 241-265.

Park, S.H., Chen, R. and Gallagher, S. (2002), 'Firm resources as moderators of the relationship between market growth and strategic alliances in semiconductor start-ups', Academy of Management Journal, Vol. $45 \mathrm{~N}^{\circ} 3$, pp. 527-545.

Pfeffer, J. and Salancik, G. (1978), The External Control of Organizations, Harper and Row, New York, NY.

Poppo, L. and Zenger, T.R. (2002), 'Do Formal Contracts and Relational Governance Function as Substitutes or Complements?', Strategic Management Journal, Vol. $23 \mathrm{~N}^{\circ} 8$, pp. 707-725.

Powell, W.W., Koput, K.W. and Smith-Doerr, L. (1996), 'Interorganizational collaboration and the locus of innovation: Networks of learning in biotechnology', Administrative Science Quarterly, Vol. 41, pp. 116-145.

Provan, K.G., Beyer, J.M. and Kruytbosch, C. (1980), 'Environmental Linkages and Power in Resource-Dependence Relations between Organizations', Administrative Science Quarterly, Vol. 25, pp. 200-225.

Qian, G. and Li, L. (2003), 'Profitability of small- and medium-sized enterprises in high-tech industries: the case of the biotechnology industry', Strategic Management Journal, Vol. $24 \mathrm{~N}^{\circ}$ 9, pp. 881-887.

Raymond, L. and St-Pierre, J. (2004), 'Customer dependency in manufacturing SMEs: implications for R\&D and performance', Journal of Small Business and Enterprise Development, Vol. $11 \mathrm{~N}^{\circ} 1$, pp. 23-33.

Reuer, J. J. and Ariño, A. (2007), Strategic alliance contracts: dimensions and determinants of contractual complexity, Strategic Management Journal, Vol. $28 \mathrm{~N}^{\circ} 3$, pp. 313-330.

Ring, P.S. and Van de Ven, A.H. (1994), 'Developmental Process of Cooperative Interorganizational Relationships', Academy of Management Review, Vol. $19 \mathrm{~N}^{\circ}$ 1, pp. 90-118.

Rubin, P.H. (1990), Managing Business Transactions, Controlling the Cost of Coordinating, Communicating and Decision Making, The Free Press, New York, NY.

Sutcliffe, K.M. and Zaheer, A. (1998), 'Uncertainty in the transaction environment: An empirical test', Strategic Management Journal, Vol. $19 \mathrm{~N}^{\circ} 1$, pp. 1-23.

Weigelt, C. (2009), 'The impact of outsourcing new technologies on integrative capabilities and performance', Strategic Management Journal, Vol. 30, pp. 595-619.

White, J.E., Gorton, M.J. and Chaston, I. (1996) 'Facilitating cooperative networks of HighTechnology small Firms: Problems and Strategies', Journal of Small Business and Enterprise Development, Vol. $3 \mathrm{~N}^{\circ}$ 1, pp. 31-47. 
Woolthuis, K., Hillebrand, R.B. and Nooteboom, B. (2005), 'Trust, control and relationship development', Organization Studies, Vol. 26 N$^{\circ}$ 6, pp. 813-840.

Yin, R. (1994), Case study research: Design and methods (2nd Ed.), Beverly Hills, CA: Sage Publishing. 